\title{
Photosynthetic index and nitrogen assimilation in rapeseed seedlings transplanted in soil with ammonium glufosinate
}

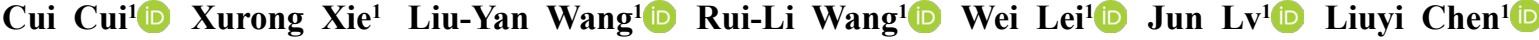 Huan-Huan Gao ${ }^{1}$ Sang Ye $^{1}$ (D) Linya Huang ${ }^{1}(\mathbb{D})$ Qing-Yuan Zhou ${ }^{1 *}(\mathbb{D}$}

${ }^{1}$ College of Agronomy and Biotechnology, Southwest University, 400715, Chongqing, China. E-mail: zhouqy2005@163.com. "Corresponding author.

ABSTRACT: Herbicide application is an effective weed control method for mitigating crop yield loss; however, herbicide overuse can cause toxicity in non-target plants. The present study evaluated the effects of glufosinate at recommended dose for agricultural application (0.45

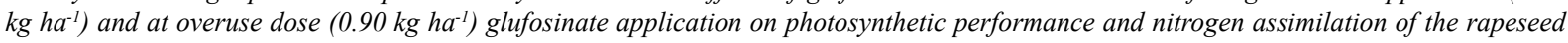
varieties D148 and Zhongshuang 11 (ZS11). Both glufosinate concentrations significantly decreased the content of chlorophyll and nitrogenous compounds, except free proline, and the activity of glutamine synthetase and glutamate synthase, and increased the activity of glutamic

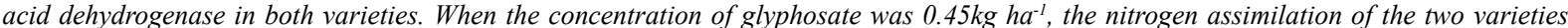
decreased, which indicated that the recommended dosage inhibited the nitrogen assimilation of the two varieties; however, the increase of net photosynthetic rate of D148 and the decrease of that of ZS11 mean that D148 is more tolerant to the recommended dose of glyphosate than ZS11. The $0.90 \mathrm{~kg} \mathrm{ha}^{-1}$ dosage was toxic to both rapeseed varieties. Overall, our results indicated that herbicide overuse inhibited the photosynthetic rate and nitrogen assimilation in rapeseed seedlings, and it is essential to apply a suitable glufosinate dose based on the variety grown to minimize adverse effects on crops and environment.

Key words: residual glufosinate, rapeseed, seedling transplanted, photosynthesis, nitrogen assimilation.

Índice fotossintético e assimilação de nitrogênio em plântulas de colza transplantadas em resposta a resíduos de glufosinato presentes no solo

RESUMO: A aplicação de herbicidas é um método eficaz de controle de ervas daninhas para mitigar a perda de produtividade das culturas. No entanto, o uso excessivo de herbicidas pode causar toxicidade em plantas não alvo. O presente estudo avaliou os efeitos da dose recomendada para aplicação agrícola $\left(0.45 \mathrm{~kg} \mathrm{ha}^{-1}\right)$ e dose excessiva $\left(0.90 \mathrm{~kg} \mathrm{ha}^{-1}\right)$ de glufosinato no desempenho fotossintético e assimilação de nitrogênio das variedades de colza D148 e Zhongshuang 11 (ZS11). Ambas as concentrações de glutamato diminuiram significativamente o teor de clorofila e compostos azotados, exceto a prolina livre, e a atividade de sintese da glutamina e de sintese de glutamato, e aumentaram a atividade de desidrogenase do ácido glutâmico em ambas as variedades. Quando a concentração de glifosato foi $0.45 \mathrm{~kg} \mathrm{ha-1}$, a assimilação de azoto das duas variedades diminuiu, o que indicou que a dosagem recomendada de glifosato inibiu a assimilação de azoto das duas variedades de colza. Entretanto, a taxa fotosintética líquida do D148 aumentou enquanto o do ZS11 diminuiu, o que significa que o D148 é mais tolerante a dose recomendada de glifosato do que o ZS11. A dose de $0.90 \mathrm{~kg} \mathrm{ha}{ }^{-1}$ de glifosato foi prejudicial para as mudas de duas variedades de colza. Em geral, os nossos resultados indicam que o uso excessivo de glufosinato inibe a taxa fotossintética e a assimilação de nitrogênio em mudas de colza, sendo essencial aplicar uma dose adequada deste herbicida com base na variedade cultivada para minimizar os efeitos adversos nas culturas e no meio ambiente.

Palavras-chave: redidual de glufosinato, colza, mudas transplantadas, fotossintese, assimilação de nitrogênio.

\section{INTRODUCTION}

Weeds are able to adapt to adverse climatic conditions and compete with crops for nutrients, water, and light, grow faster than crops, and reduce their yield (SUKSUNGWORN et al., 2016). Weed species are considered the main biological constraint in crop production, and thus, it is crucial to address their management (BALOCH et al., 2005; AWAN et al., 2016). Herbicide application is one of the most common measures for controlling weeds and avoiding yield loss during crop production, as it is cheaper and more efficient than other weed control practices (KHALIQ \& MATLOOB, 2012; ÁY et al., 2012; AWAN et al., 2016). Due to its increased use in global crop production, the herbicide market grew by $39 \%$ from 2002 to 2011, especially in developing countries (GIANESSI, 2013; VÍTEK et al., 2017).

Some studies have shown that weed control becomes more expensive and more difficult if herbicides are not applied at pre-emergence or early growth stages (SINGH et al., 2006; MAHAJAN \& CHAUHAN, 
2013; AWAN et al., 2016). However, to improve weed control, farmers often apply an overdose of herbicides, resulting in a series of problems, including those caused by pre-emergent herbicides on seed germination and seedling growth (KEARNEY \& KAUFMAN, 1975; SINGH et al., 2006; KHALIQ \& MATLOOB, 2012; MAHAJAN \& CHAUHAN, 2013; SUKSUNGWORN et al., 2016; AWAN et al., 2016). These herbicide treatments cause phytotoxicity, which inhibits vital processes in nontarget plants, such as cell division, mineral uptake, and the incorporation of amino acids into proteins, and ultimately influences the growth of seedlings (KEARNEY \& KAUFMAN, 1975; KHALIQ \& MATLOOB, 2012; AWAN et al., 2016). Herbicide overuse leads to a high level of resistance in weeds; for instance, triazine resistance was reported in 1970 (RYAN 1970), followed by reports of resistance to several other herbicides in weeds (BANDEEN et al., 1982; GRESSEL et al., 1982). In addition, increasing herbicide application has led to environmental pollution and human health problems (APREA et al., 2002; LAITINEN et al., 2006; SINGH, 2006; ALI et al., 2008; TEERARAK et al., 2012; BADR ET AL., 2013; SUKSUNGWORN et al., 2016).

Herbicides can be divided into two types: selective herbicides, designed to kill only specific plants, and non-selective herbicides, which kill all plants. Glufosinate is a non-selective herbicides (WENDLER et al., 1990), and is used for broad spectrum control of grass and broadleaf weed species (JALALUDIN et al., 2017). Glufosinate-containing herbicides are widely marketed, and the gradual increase in their use in many countries was mainly due to manufacturers claiming that glufosinate has a favorable safety profile for both humans and the environment (MAO et al., 2012). Glufosinate is a "contact" herbicide and requires higher usage rates that may pose a higher risk to the environment (XU et al., 2016). As a phosphonic acid analog of glutamate, it potently inhibits the activity of glutamine synthetase (GS), a key enzyme in nitrate assimilation, by competing with glutamate for binding sites in an irreversible way (MANDERSCHEID \& WILD 1986; LOGUSCH et al. 1991). This process leads to the accumulation of toxic ammonium and reduces the photosynthetic activity of the plant, resulting in the accumulation of reactive oxygen species. So, there are several causes that lead to plant death when treated with glufosinate (XIE et al. 2014).

Rapeseed is one of the most important oil crops of the genus Brassica in China-it represents up to one third of the country's total planted area and total crop yield. However, weeds can be one of the most limiting factors in rapeseed production. In winter fields, where weeds are not properly controlled, yield losses can reach 10-30\%, or more than 50\% (ROLA \& FRANEK, 1985), because rapeseed does not compete well with weeds in its early growth stages owing to its slow growth and slow spreading on the ground. Thus, weeds must be controlled early in rapeseed development to avoid yield loss due to this competition. This is achieved by chemical weeding, one of the most important agricultural activities preceding rapeseed seedlings transplantation. Glufosinate is widely used before rapeseed sowing or transplantation in the southwestern region of China, and yet there is little information on its toxicity to transplanted rapeseed seedlings, especially considering the presence of glufosinate residues in the soil.

Extensive utilization of herbicides increase unwanted soil residues. These residues are harmful and raise concern about the ecological impact of herbicides (ROTCHES-RIBALTA et al., 2015), challenging the paradigm of weed management strategies based on herbicide use (GABA et al., 2017). Residual phytotoxic effects can be used to detect herbicide or chemical residue present in the soil at concentrations high enough to adversely affect crop growth, yield, and quality (PESTEMER et al., 1980). In the present study, non-transgenic Brassica napus lines D148 and Zhongshuang 11 (ZS11) transplanted seedlings was used to evaluate the effects of the glufosinate sprayed on test plots before rapeseed seedling transplantation on the photosynthetic rates and nitrogen metabolism at three different concentrations: $0 \mathrm{~kg} \mathrm{ha}^{-1}$ (control), $0.45 \mathrm{~kg} \mathrm{ha}^{-1}$ (recommended dose), and $0.90 \mathrm{~kg} \mathrm{ha}^{-1}$ (overuse dose). The aim was to evaluate the effects of glufosinate at recommended dose and overuse dose on photosynthetic performance and nitrogen assimilation of the rapeseed.

\section{MATERIALS AND METHODS}

\section{Field experiments}

Field experiments were conducted on a farm at Southwest University $\left(29^{\circ} 51^{\prime} \mathrm{N}, 106^{\circ} 27^{\prime} \mathrm{E}\right.$; $244 \mathrm{~m}$ altitude) in 2015 and 2016 . The local climate is a sub-tropical climate (ANJUM et al., 2016), with an average temperature of $18^{\circ} \mathrm{C}, 1,276.7 \mathrm{~h}$ of sunshine, and $1,133.7 \mathrm{~mm}$ of annual rainfall. The soil type is a dry land purple soil with an even and consistent fertility status and $\mathrm{pH} 6.46$. The chemical composition in a $20-\mathrm{cm}$ plow horizon are analyzed according to Bao`s methods (BAO, 2000), and included: organic 
matter, $28.2 \mathrm{~g} \mathrm{~kg}^{-1}$; total nitrogen (TN), $1.36 \mathrm{~g} \mathrm{~kg}^{-1}$; phosphate, $1.35 \mathrm{~g} \mathrm{~kg}^{-1}$; potassium, $10.4 \mathrm{~g} \mathrm{~kg}^{-1}$; alkali nitrogen, $34.91 \mathrm{mg} \mathrm{kg}^{-1}$; available phosphate, 18.13 $\mathrm{mg} \mathrm{kg}{ }^{-1}$; and available potassium, $268.23 \mathrm{mg} \mathrm{kg}^{-1}$. Flax and corn were planted as a formal crop in this field at 2015 and 2016.

\section{Experimental design}

The two-factor randomized block design with three replications included two rapeseed varieties and three herbicide concentrations. Non-transgenic Brassica napus lines D148 and Zhongshuang 11 (ZS11) were used as experimental materials. These lines were provided by the Chongqing Rapeseed Technology Research Centre (Chongqing, China). The ZS11 cultivar is cultivated widely in the Yangtze valley; it is derived from the progenies of Zhongshuang96/2F10//26102 and bred by the Oil Crop Research Institute of the Chinese Academy of Agricultural Sciences. D148 is a selfprogeny breeding line of Youyan10, and it was bred by the Guizhou Academy of Agricultural Science, China. Herbicide solution $\left(200 \mathrm{~g} \mathrm{~L}^{-1}\right)$ with the active ingredient glufosinate-ammonium (Veyong BioChemical Co., Ltd., Hebei, China) was used at three different concentrations: $0 \mathrm{~kg} \mathrm{ha}^{-1}$ (control), $0.45 \mathrm{~kg}$ $\mathrm{ha}^{-1}$, and $0.90 \mathrm{~kg} \mathrm{ha}^{-1}$. The recommended dose for agricultural application is $0.45 \mathrm{~kg} \mathrm{ha}^{-1}$, and $0.90 \mathrm{~kg}$ $\mathrm{ha}^{-1}$ is an extreme dose of the herbicide.

Two rapeseed varieties were sown in seedling beds for germination in October 5, 2015 and 2016, respectively. Two glufosinate concentrations and control were sprayed $50 \mathrm{~cm}$ above the ground in an experimental field using a knapsack sprayer with a spray volume of $350 \mathrm{~L} \mathrm{ha}^{-1}$, spray pressure of 0.2 $\mathrm{MPa}$, and spray speed of $20 \mathrm{~cm} \mathrm{~s}^{-1}$. Five days after this application; i.e., on November 7, 2015 and 2016; respectively, healthy seedlings of both rapeseed varieties at the 4-5-leaf stage were transplanted from the seedling beds to this glufosinate-treated experimental field. Each block area included 25 squares $(5 \mathrm{~m} \times 5 \mathrm{~m})$ organized in three replicates, rows were $50 \mathrm{~cm}$ apart, and contained 20 plants separated by $25 \mathrm{~cm}$. Two rows were planted between neighboring blocks to reduce the influence of neighboring blocks. Similarly, the entire experimental field was separated from the surroundings by means of four rows. A 50-cm corridor was placed between the different experimental blocks. The experimental field was managed using the methods applied in a farmer's field. Nine days after transplantation, the photosynthetic index and nitrogen assimilation parameters were measured to evaluate the effect of the two concentrations of glufosinate applied to the soil on the growth of transplanted rapeseed seedlings.

\section{Measurement of parameters}

A portable photosynthesis system (LI6400; LI-COR Biosciences, Lincoln, NE, USA) was used to measure the net photosynthetic rate $\left(\mathrm{P}_{\mathrm{n}}\right)$, stomatal conductance $\left(\mathrm{G}_{\mathrm{s}}\right)$, intercellular $\mathrm{CO}_{2}$ concentration $\left(\mathrm{C}_{\mathrm{i}}\right)$, and transpiration rate $\left(\mathrm{T}_{\mathrm{r}}\right)$ from the third fully expanded upper leaf in five randomly selected seedlings within each treatment group. The measurements were taken between 09:00 and 11:00 $\mathrm{h}$ with the device that used an LED light source set at $500 \mathrm{~mol}$ photon $\mathrm{m}^{-2} \mathrm{~s}^{-1}$. The $\mathrm{CO}_{2}$ level in the chamber was maintained at $400 \mu \mathrm{mol} \mathrm{mol}{ }^{-1}$, leaf to air vapor pressure deficit was $1.7-2.6 \mathrm{kPa}$, leaf temperature was $20-22^{\circ} \mathrm{C}$, and air flow was $500 \mathrm{~mol} \mathrm{~s}^{-1}$.

Five plants were carefully removed from each plot with their roots and leaves intact. After cleaning, the leaves and roots were cut from the plants and pooled into leaf and root samples, respectively. From each sample of fresh leaves, $0.2 \mathrm{~g}$ per sample was used to measure chlorophyll (Chl) content and 6 g was dried at $80^{\circ} \mathrm{C}$ for total nitrogen $(\mathrm{TN})$ content determination. The remaining leaf and root samples were stored at $-80^{\circ} \mathrm{C}$ until their use for measuring glutamine synthetase (GS), glutamate synthase (GOGAT), and glutamate dehydrogenase (GDH) activity; in addition, soluble protein (SP), free amino acid (FAA), and proline (Pro) content was measured from leaves stored at $-80^{\circ} \mathrm{C}$. In the present study, Chl content was determined by using acetone extraction method as ascribed by HAO (2004). The GS activity was measured according to Hao's method (2004). The activity of GOGAT was measured following the method of SINGH \& SRIVASTAVA (1986). The activity of GDH, an oxidoreductase that is widely reported in plants, was determined following TANG (1999). Soluble protein (SP) content was determined with th method of Coomassie Brilliant Blue G-250 staining (HAO, 2004). The content of total nitrogen (TN) was determined by the Kjeldahl nitrogen method (HAO, 2004). Free amino acid (FAA) content was determined by the hydrated ninhydrin colorimetric method (ZOU, 1995). Free proline (Pro) accumulation was determined using the method of BATES et al. (1973).

\section{Data analyses}

All the data were statistically evaluated using Microsoft Excel (Microsoft, Redmond, WA, USA) and DPS 14.10 (Zhejiang University, Hangzhou, China). Significant differences among herbicide 
treatments were compared by Duncan's multiple range test, considering $P<0.05$ and $P<0.01$ as threshold levels. Under the same glufosinate concentration, some treatments had significant differences between different varieties $(P<0.05)$; consequently, significant differences were tested among different concentration treatments for each variety.

\section{RESULTS}

Effects of glufosinate on the photosynthetic index

$\mathrm{Chl}$ content was significantly lower in both rapeseed varieties treated with glufosinate as compared to that in control plants (Figure 1A), indicating that glufosinate inhibited $\mathrm{Chl}$ biosynthesis. The highest concentration of glufosinate further limited Chl biosynthesis in rapeseed seedlings as compared to that of the control and plants treated with the recommended dose. During the two years field experiments, the Chl content of ZS11 significant decreased at $0.45 \mathrm{~kg} \mathrm{ha}^{-1}$, and $0.90 \mathrm{~kg} \mathrm{ha}^{-1}$ glufosinate. These reduction were more severe than that in D148 at the same glufosinate concentrations.

Our results showed that the $P_{\mathrm{n}}$ of D148 were significant higher at $0.45 \mathrm{~kg} \mathrm{ha}^{-1}$ glufosinate during two years field experiments, while that were significant lower than the control at $0.90 \mathrm{~kg} \mathrm{ha}^{-1}$ glufosinate (Figure 1B). Whereas the $P_{\mathrm{n}}$ of $\mathrm{ZS} 11$ significant decreased at $0.45 \mathrm{~kg} \mathrm{ha}^{-1}$ and $0.90 \mathrm{~kg}$ $\mathrm{ha}^{-1}$ glufosinate concentrations, as compared to that in control plants. In addition, the $T_{\mathrm{r}}$ and $G_{\mathrm{s}}$ in D148 were enhanced at both glufosinate concentrations, whereas that of ZS11 decreased with glufosinate treatment (Figure 1C, Figure 1D). The $C_{\mathrm{i}}$ of D148

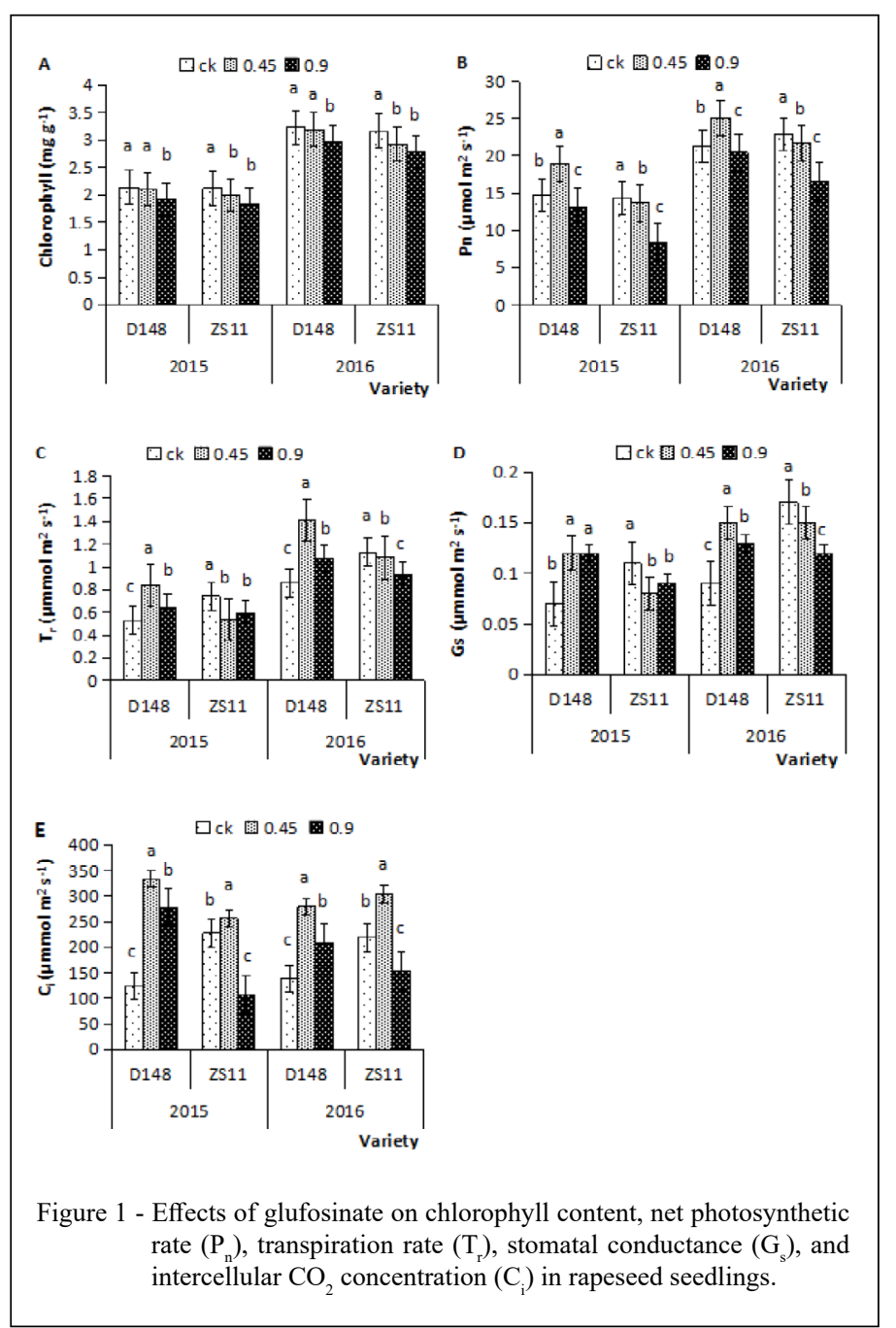

Ciência Rural, v.50, n.4, 2020. 
plants significantly increased at both glufosinate concentrations $(169.35 \%$ and $101.51 \%$ at $0.45 \mathrm{~kg}$ $\mathrm{ha}^{-1}$ in 2015 , and $124.82 \%$ and $50.75 \%$ at $0.90 \mathrm{~kg}$ $\mathrm{ha}^{-1}$ glufosinate in 2016) as compared to that in the control plants, but that of ZS11 seedlings significantly decreased by $53.12 \%$ and $29.72 \%$ in the $0.90 \mathrm{~kg} \mathrm{ha}^{-1}$ glufosinate treatment, as compared to that in control plants (Figure 1E). Overall, the photosynthesis was significantly improved by the application of the recommended dose of glufosinate in D148 but it was limited in ZS11 rapeseed seedlings.

\section{Effects of glufosinate on enzymes regulating nitrogen assimilation}

GS and GOGAT showed similar activity, but that of GDH differed (Figure 2). Specifically, the activity of GS and GOGAT in the roots and leaves of both rapeseed varieties decreased under both glufosinate treatments during two years experiments
(Figure 2A, Figure 2B, Figure 2C, Figure 2D). When glufosinate was overused, GS activity in roots of D148 and ZS11 was minimal and decreased by $15.62 \%$ and $17.19 \%$ in 2015 respectively, while that GS in leaves decreased by $9.84 \%$ and $9.68 \%$; respectively, and similar changes happened in 2016. Therefore, glufosinate had stronger adverse effects on the activity of GS in roots than on the GS activity in leaves. In addition, with $0.90 \mathrm{~kg} \mathrm{ha}^{-1}$ glufosinate treatment, GOGAT activity in the leaves and roots of both varieties was significantly $(P<0.05)$ lower than that in the control plants, specifically, GOGAT activity in leaves decreased by $8.49 .11 \%$ to $13.86 \%$, while that in roots decreased by $4.90 \%$ to $11.76 \%$.

After glufosinate application, the activity of GDH in the leaves and roots of treated plants from both rapeseed varieties was significantly higher $(P<0.05)$ than that in the control plants (Figure 2E, Figure $2 \mathrm{~F}$ ). However, the GDH in leaves increased

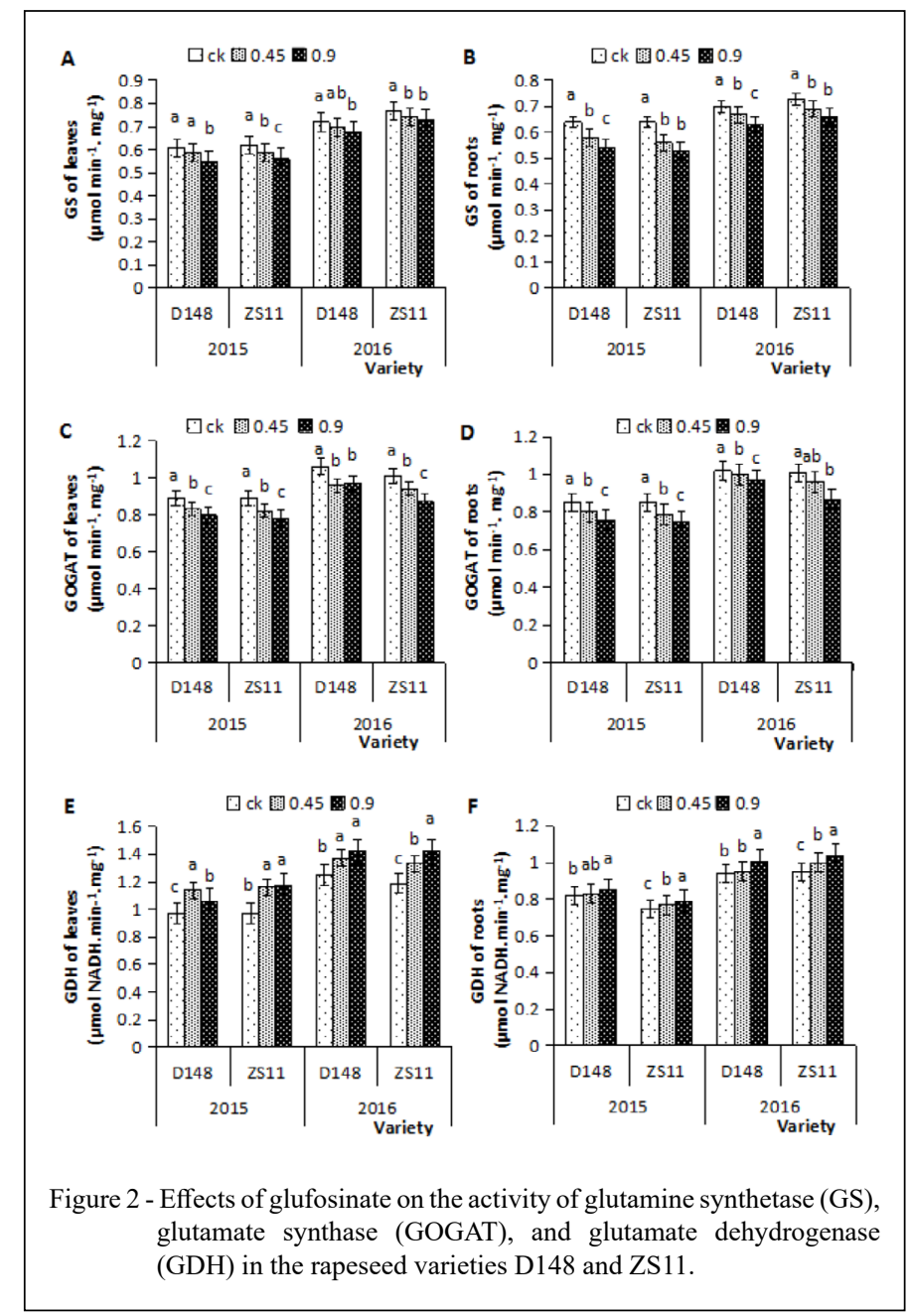

Ciência Rural, v.50, n.4, 2020. 
by $9.28 \%$ to $20.62 \%$, whereas that in roots increased by $1.06 \%$ to $9.47 \%$ in both varieties. This indicated that the GDH activity was more strongly affected in leaves than in roots. In addition, the increase in GDH activity in D148 leaves was less than that in ZS11 leaves.

\section{Effects of glufosinate on nitrogen accumulation in rapeseed leaves}

TN, SP, and FAA in the leaves of both rapeseed varieties decreased significantly $(P<0.05)$ after $0.90 \mathrm{~kg} \mathrm{ha}^{-1}$ glufosinate application, by $6.79 \%$, $2.42 \%$, and $3.23 \%$ at 2015 and $8.05 \%, 8.47 \%$, and $6.19 \%$ at 2016 in D148, and by $8.05 \%, 5.16 \%$, $3.37 \%$ at 2015 and $7.94 \%, 8.69 \%$, and $8.64 \%$ at 2016 in ZS11, respectively, than that in the control plants (Figure 3). SP may also play an important role in stabilizing the structure of biological macromolecules by reducing the acidity of cells and decreasing ammonia toxicity.

\section{DISCUSSION}

Glufosinate is a broad-spectrum herbicide, and its half-life is 2-8 days. Weeds usually turn yellow after 3 days of glufosinate spraying and die after 7 days of glufosinate spraying. As the dissipation of the herbicide increases with the passage of time, residue is reduced. Therefore, According to the half-life of glufosinate and the transplanting habits of farmers in Chongqing after chemical weeding, seedlings were transplanted 5 days after spraying. In addition, environmental conditions, like temperature and rainfall, are important factors influencing the breakdown of glufosinate. Breakdown of glufosinate was faster in soils at $20{ }^{\circ} \mathrm{C}$ than at $10{ }^{\circ} \mathrm{C}$. The time required for $50 \%$ of the glufosinate in the soil to be degraded ranged from 3 to $7 \mathrm{~d}$ at $20^{\circ} \mathrm{C}$, and from 8 to $11 \mathrm{~d}$ at $10{ }^{\circ} \mathrm{C}$ (SMITH, 1988). The amount of rainfall not only raised soil moisture content, but determined the degree of glufosinate leaching. Hence, higher

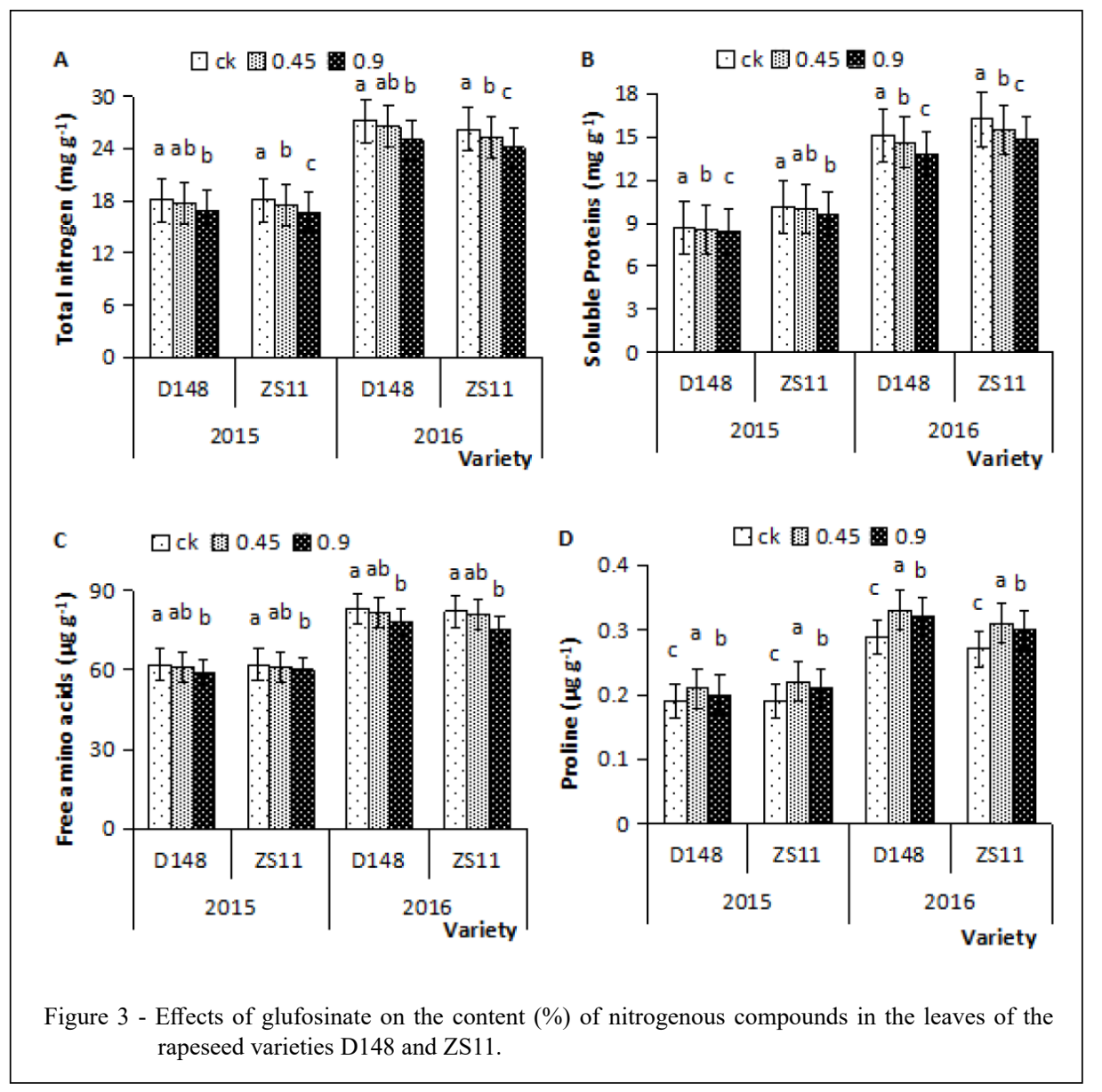

Ciência Rural, v.50, n.4, 2020. 
temperature and rainfall are helpful to accelerate breakdown and decrease residual glufosinate. During the experiment, the average temperature and rainfall were $15.6{ }^{\circ} \mathrm{C}$ and $9.7 \mathrm{~mm}$ in $2015,13.8$ ${ }^{\circ} \mathrm{C}$ and $67.2 \mathrm{~mm}$ in 2016 , respectively. Obviously, average temperature was similar but rainfall was 7 times higher in 2016 than in 2015 after glufosinate treatment. This may be result the precipitation increased after spraying with glufosinate in 2016, which accelerated the degradation of glufosinate and weakened the effect on nitrogen metabolism of rape transplanting seedlings.

Nitrogen is an important macronutrient for the synthesis of fundamental molecules, such as proteins, nucleotides, and cellular components. Its assimilation in plants plays a primary role in amino acid synthesis and conversion through the reduction of nitrate (XIE et al., 2014). Most higher plants absorb inorganic nitrogen in the form of $\mathrm{NO}_{3}^{-}$or $\mathrm{NH}_{4}^{+}$from the environment. Absorbed $\mathrm{NH}_{4}^{+}$is then assimilated into glutamine and glutamate via the action of GS and GOGAT, which is known as the GS/GOGAT cycle (MIFLIN et al., 1980; DU et al., 2014). Glufosinate targets GS (LEA et al., 1984; BELLINDER et al., 1985) and potently inhibits its activity by competing with glutamate for binding sites in an irreversible way (LOGUSCH et al., 1991). This process leads to the accumulation of toxic ammonium and decreases the L-glutamine synthesis in the cell, which in turn decreases the levels of amino acid precursors in protein synthesis (ROJANO-DELGADO et al., 2013). Thus, the inhibition of GS by glufosinate is metabolically reflected in the in vivo accumulation of ammonium and in the decrease in glutamine, as reported in several crops (LEASON et al., 1982; ERICSON, 1985; MANDERSCHEID \& WILD, 1986). However, to improve weed control, farmers often apply an overdose of herbicides, which stimulates a high level of weed resistance, causing toxicity to non-target plants and environmental pollution. In this study, glufosinate application decreased GS and GOGAT activity and enhanced GDH activity in both rapeseed varieties, even at the recommended glufosinate application level; although, $90 \mathrm{~kg} \mathrm{ha}^{-1}$ glufosinate caused the strongest symptoms of phytotoxicity in both varieties. Similar changes in GOGAT activity observed in the roots and leaves of both rapeseed varieties might be due to the two different plastidlocalized forms of GOGAT present in higher plants: ferredoxin-dependent (Fd-GOGAT) and NADH-dependent (NADH-GOGAT). Fd-GOGAT is the predominant form in leaves, whereas NADHGOGAT exists in roots (LANCIEN et al., 2002). In contrast, GS activity decreased more in roots than in leaves, whereas GDH presented the opposite trend in both rapeseed varieties grown at both glufosinate concentrations. Because GDH participated in the metabolism of protein-derived amino acids, this metabolic route is particularly important as a response to stress or carbohydrate starvation. This indicated that glutamine and protein synthesis from $\mathrm{NH}_{4}^{+}$were inhibited in the roots. Moreover, the enhancement of GDH activity showed that glufosinate had a greater effect on leaves than on roots of rapeseed seedlings. The decline in GS and GOGAT activity, and the enhancement of GDH activity, highlighted that the residual effects of glufosinate weakens nitrogen assimilation in rapeseed seedlings even when glufosinate is applied at the recommended dose. This finding was confirmed by the significant decrease in $\mathrm{TN}, \mathrm{SP}$, and FAA measured in both rapeseed varieties at both glufosinate concentrations. Thus, glufosinate interferes with amino acid synthesis through the inhibition of GS activity (KISHORE et al., 1988; ÁY et al., 2012). Additionally, the increase in proline content suggested its role as an osmotic adjustment that protects the cell from damage under herbicide stress.

Photosynthesis and vegetative growth are closely linked, and when photosynthesis is inhibited under adverse conditions, vegetative growth usually slows or even stops. Because stomata are the main channels for gas exchange between plant leaves and the external environment, stomatal conductance affects photosynthesis, respiration, and transpiration. This study evaluated the photosynthetic rates in rapeseed seedlings after glufosinate application. Results showed that 0.45 and $0.90 \mathrm{~kg} \mathrm{ha}^{-1}$ glufosinate applications significantly decreased chlorophyll content in both rapeseed varieties and limited the biosynthesis of chlorophyll, whereas the overdose concentration of glufosinate significantly inhibited the net photosynthetic rates in the seedlings of both rapeseed varieties. Photosynthetic inhibition by glufosinate was previously described (WENDLER et al., 1990); it is caused by the inhibition of glutamine production, leading to a breakdown in photosynthesis (WENDLER et al., 1990). Since glufosinate is a non-selective herbicide, both crop and weed species are affected. Reduction in photosynthetic activity might also be attributed to the reduction in chlorophyll content and/or abnormalities in the structure and function of chloroplasts. However, glufosinate susceptibility differs markedly among plants (RIDLEY \& MCNALLY, 1985). Thus, the net photosynthetic rate of D148 increased at 
the recommended glufosinate dose; although, chlorophyll content was reduced, suggesting that rapeseed varieties have evolved different responses to herbicide exposure or treatment. The D148 variety is relatively more tolerant to low concentrations of glufosinate compared to ZS11, and it can quickly restore photosynthesis. Overuse of herbicides induced more damage to the crop plant than is necessary; therefore, the most effective method to achieve weed control with herbicides is the development of nontransgenic crop cultivars with herbicide tolerance (ÁY et al., 2012).

Although, photosynthesis and nitrogen accumulation were affected by glufosinate in the seedlings of both rapeseed varieties, they responded differently to the recommended glufosinate dose. Still, glufosinate at $0.90 \mathrm{~kg} \mathrm{ha}^{-1}$ displayed the highest phytotoxicity in both varieties in this study. Our results for rapeseed are consistent with the findings of AWAN et al. (2016), who reported that herbicide treatment concentration is an important factor influencing phytotoxicity of the herbicide to rice. Further, the present study highlighted how glufosinate application affects a non-target crop. Low doses of herbicides may not cause crop damage, but certain concentrations, particularly extreme concentrations of herbicides, can negatively affect photosynthetic rates and nitrogen assimilation in seedlings, leading to crop injury. Furthermore, some weeds might develop resistance to herbicides after being exposed to the same herbicide over several generations and can then dominate a crop field ecosystem. Therefore, to reduce its influence on non-target crop plants, it is very important to use suitable doses in accordance with the plant variety before sowing seeds or transplanting seedlings into treated fields, and integrated weed management is a critical strategy for growers to protect non-target species from the risks associated with unintended herbicide exposure.

\section{CONCLUSION}

In summary, residual glufosinate in the soil induced physiological phytotoxicity on photosynthesis and nitrogen accumulation of transplanted rapeseed seedlings belonging to ZS11 and D148 varieties, but D148 variety is relatively more tolerant to low concentrations of glufosinate compared to ZS11. Meanwhile, overuse of herbicides induces more damage to the crop plant than is recommended concentration of herbicides. Therefore, one of the effective methods to achieve weed control with herbicides is the development of non-transgenic crop cultivars with herbicide tolerance, and integrated weed management is a critical strategy for growers to protect non-target species from the risks associated with unintended herbicide exposure.

\section{ACKNOWLEDGEMENTS}

This work was supported by the National Key Research and Development Program in China (2018YFD0100500), and the Chongqing Municipal Science and Technology Innovation Project (cstc2019jscx-msxmX0383).

\section{DECLARATION OF CONFLICT OF INTEREST}

The authors declare no conflict of interest. The founding sponsors had no role in the design of the study; in the collection, analyses, or interpretation of data; in the writing of the manuscript, and in the decision to publish the results.

\section{AUTHORS' CONTRIBUTIONS}

All authors contributed equally to this work and manuscript preparation.

\section{REFERENCES}

ALI, D. et al. Genotoxicity assessment of acute exposure of chlorpyrifos to freshwater fish Channa punctatus (Bloch) using micronucleus assay and alkaline single-cell gel electrophoresis. Chemosphere, v.71, p.1823-1831, 2008. Available from: $<$ https:// doi.org/10.1016/j.chemosphere.2008.02.007>. Accessed: Jan. 02, 2020. doi: 10.1016/j.chemosphere.2008.02.007.

ANJUM, S.A et al. Exogenously applied methyl jasmonate improves the drought tolerance in wheat imposed at early and late developmental stages. Acta Physiologiae Plantarum, v.38, p.25, 2016. Available from: <https://doi.org/10.1007/s11738-015-20479>. Accessed: Jan. 02, 2020. doi: 10.1007/s11738-015-2047-9.

APREA, C., et al. Biological monitoring of pesticide exposure: a review of analytical methods. Journal of Chromatography B, v.769, p.191-219, 2002. Available from: <https://doi.org/10.1016/ s1570-0232(02)00044-2>. Accessed: Feb. 5, 2016. doi: 10.1016/ s1570-0232(02)00044-2.

AWAN, T.H. et al. Effect of pre-emergence herbicides and timing of soil saturation on the control of six major rice weeds and their phytotoxic effects on rice seedlings. Crop Protection, v.83, p.37-47, 2016. Available from: <https://doi.org/10.1016/j. cropro.2016.01.013>. Accessed: Jan. 02, 2020. doi: 10.1016/j. cropro.2016.01.013.

ÁY, Z., et al. The effect of high concentrations of glufosinate ammonium on the yield components of transgenic spring wheat (Triticum aestivum L.) constitutively expressing the bar gene. The Scientific World Journal, v.1-9, 2012. Available from: <https:// doi.org/10.1100/2012/657945>. Accessed: Jan. 02, 2020. doi: $10.1100 / 2012 / 657945$.

BADR, A. et al. Cytophysiological impacts of Metosulam herbicide on Vicia faba plants. Acta Physiologiae Plantarum, v. 
35, p.1933-1941, 2013. Available from: <https://doi.org/10.1007/ s11738-013-1232-y>. Accessed: Jan. 02, 2020. doi: 10.1007/ s11738-013-1232-y.

BALOCH, M.S., et al. Weeding techniques in transplanted and direct wet-seeded rice in Pakistan. Weed Biology and Management, v.5, p.190-196, 2005. Available from: https://doi. org $/ 10.1111 / \mathrm{j} .1445-6664.2005 .00180 . \mathrm{x}>$. Accessed: Jan. 02, 2020. doi: 10.1111/j.1445-6664.2005.00180.x.

BANDEEN, J.D., et al. Discovery and distribution of herbicideresistant weeds in North America. In H.M. LeBaron, J. Gressel, eds. Herbicide Resistance in Plants. New York: John Wiley \& Sons, 1982. p.9-30

BAO, S.D. Soil and Agricultural Chemistry Analysis. Beijing, China: China Agriculture Press, 2000. Chap.3, p.25-114.

BATES, L.S., et al. 1973. Rapid determination of free proline for water stress studies. Plant and Soil, v.39, p.205-207, 1973. Available from: $<$ https://doi.org/10.1007/BF00018060 $>$. Accessed: Jan. 02, 2020. doi: 10.1007/BF00018060.

BELLINDER, R.R., et al. Mode of action investigations with the herbicides HOE-39866 and SC-0224. Weed Science, v.33, p.779-785, 1985. Available from: <https://doi.org/10.1017/ S004317450008334X>. Accessed: Jan. 02, 2020. doi: 10.1017/ S004317450008334X

DU, C.Q. et al. Molecular cloning, characterization and function analysis of a GDH gene from Sclerotinia sclerotiorum in rice. Molecular Biology Reports, v.41, p.3683-3693, 2014. Available from: https://doi.org/10.1007/s11033-014-3233-3>. Accessed: Jan. 02, 2020. doi: 10.1007/s11033-014-3233-3.

ERICSON, M.C. Purification and properties of glutamine synthetase from spinach leaves. Plant Physiology, v.79, p.923927, 1985. Available from: <https://doi.org/10.1104/pp.79.4.923> Accessed: Jan. 02, 2020. doi: 10.1104/pp.79.4.923.

GABA, S., et al. Response and effect traits of arable weeds in agro-ecosystems: a review of current knowledge. Weed Research. v.57, p.123-147, 2017. Available from: <https://doi.org/10.1111/ wre.12245>. Accessed: Jan. 02, 2020. doi: 10.1111/wre.12245.

GIANESSI, L.P. The increasing importance of herbicides in worldwide crop production. Pest Management Science, v.69, p.1099-1105, 2013. Available from: <https://doi.org/10.1002/ ps.3598>. Accessed: Jan. 02, 2020. doi:10.1002/ps.3598.

GRESSEL, J., et al. Discovery and distribution of herbicideresistant weeds outside North America. In: LE BARON H.M.; Gressel, J. eds, Herbicide Resistance in Plants. New York: John Wiley \& Sons, 1982. p.31-55.

HAO, Z., et al.. Plant Physiology Experiment. Harbin, China: Harbin Institute of Technology Press, 2004. Chap.6, p.67-70.

JALALUDIN, A., et al. Characterisation of glufosinate resistance mechanisms in Eleusine indica. Pest Management Science, v.73, p.1091-1100, 2017. Available from: <https://doi.org/10.1002 ps.4528>. Accessed: Jan. 02, 2020. doi: 10.1002/ps.4528.

KEARNEY, P.C.; KAUFMAN, D.D. Herbicides: Chemistry, degradation and mode of action. $2 \mathrm{~d}$ ed. New York: Marcel Dekker Inc., 1975. p.20-50.
KHALIQ, A.; MATLOOB, A. Germination and growth response of rice and weeds to herbicides under aerobic conditions. International Journal of Agriculture and Biology, v.14, p.775 780, 2012. Available from: <https://doi.org/10.3906/tar-1112-44>. Accessed: Jan. 02, 2020. doi:10.3906/tar-1112-44.

KISHORE, G.M., et al. Amino acid biosynthesis inhibitors as herbicides. Annual Review of Biochemistry, v. 57, p.627663, 1988. Available from: <https://doi.org/10.1146/annurev. bi.57.070188.003211>. Accessed: Jan. 02, 2020. doi: 10.1146/ annurev.bi.57.070188.003211.

LAITINEN, P., et al. Fate of the herbicides glyphosate, glufosinateammonium, phenmedipham, ethofumesate and metamitron in two Finnish arable soils. Pest Management Science, v.62, p.473491, 2006. Available from: <https://doi.org/10.1002/ps.1186>. Accessed: Jan. 02, 2020. doi:10.1002/ps.1186.

LANCIEN, M., et al. Arabidopsis glt1-T mutant defines a role for NADH-GOGAT in the non-photorespiratory ammonium assimilatory pathway. The Plant Journal, v.29, p.347-358, 2002. Available from: https://doi.org/10.1046/j.1365-313X.2002.01218.x>. Accessed: Jan. 02, 2020. doi: 10.1046/j.1365-313X.2002.01218.x.

LEA, P.J., et al. The action of 2-amino-4-(methylphosphinyl)butanoic acid (phosphinothricin) and its 2-oxo-derivative on the metabolism of cyanobacteria and higher plants. Phytochemistry, v.23, p.1-6, 1984. Available from: https://doi.org/10.1016/00319422(84)83066-6>. Accessed: Jan. 02, 2020. doi:10.1016/00319422(84)83066-6.

LEASON, M., et al. Inhibition of pea leaf glutamine synthetase by methionine sulphoximine, phosphinothricin and other glutamate analogues. Phytochemistry, v.21, p.855-857, 1982. Available from: https://doi.org/10.1016/0031-9422(82)80079-4>. Accessed: Jan. 02, 2020. doi:10.1016/0031-9422(82)80079-4.

LOGUSCH, E.W., et al. Inhibition of plant glutamine synthetases by substituted phosphinothricins. Plant Physiology, v.95, p.1057-1062, 1991. Available from: <https://doi.org/10.1104/ pp.95.4.1057>. Accessed: Jan. 02, 2020. doi:10.1104/pp.95.4.1057.

MANDERSCHEID, R.; WILD, A. Studies on the mechanism of inhibition by phosphinothricin of glutamine synthetase isolated from Triticum aestivum L. Journal of Journal of Plant Physiology, v.123, p.135-142, 1986. Available from: <https://doi.org/10.1016/ S0176-1617(86)80134-1>. Accessed: Jan. 02, 2020. doi:10.1016/ S0176-1617(86)80134-1.

MAO, Y.C. et al. Acute human glufosinate-containing herbicide poisoning. Clinical Toxicology, v.50, p.396-402, 2012. Available from: <https://doi.org/10.3109/15563650.2012.676646>. Accessed: Jan. 02, 2020. doi: $10.3109 / 15563650.2012 .676646$.

MAHAJAN, G.; CHAUHAN, BS. Herbicide options for weed control in dry-seeded aromatic rice in India. Weed Technology, v.27, p.682-689, 2013. Available from: <https://doi.org/10.1614/WT-D-1300016.1>. Accessed: Jan. 02, 2020. doi:10.1614/WT-D-13-00016.1.

MIFLIN, B.J.; LEA, PJ. Ammonia assimilation. In: MIFLIN, B. J. (ed). The Biochemistry of Plants. New York, United States: Academic Press, 1980. p.99-143.

PESTEMER, W., et al. Availability to plants of herbicide residues in soil. Part II: Data for use in vegetable crop rotations. Weed 
Research, v.20, p.349-353,1980. Available from: <https://doi. org/10.1111/j.1365-3180.1980.tb00082.x>. Accessed: Jan. 02, 2020. doi:10.1111/j.1365-3180.1980.tb00082.x.

RIDLEY, S.M.; McNally, SF. Effect of phosphinothricin on the isoenzymes of glutamine synthetase isolated from plant species which exhibit varying degrees of susceptibility to the herbicide. Plant Science, v. 39, p. 31-36, 1985. Available from: https://doi. org/10.1016/0168-9452(85)90188-8>. Accessed: Jan. 02, 2020. doi: $10.1016 / 0168-9452(85) 90188-8$.

ROJANO-DELGADO, A.M., et al. Liquid chromatography-diode array detection to study the metabolism of glufosinate in Triticum aestivum T-590 and influence of the genetic modification on its resistance. Phytochemistry, v.96, p.117-122, 2013. Available from: $\quad<$ https://doi.org/10.1016/j.phytochem.2013.10.008> Accessed: Jan. 02, 2020. doi: 10.1016/j.phytochem.2013.10.008.

RYAN, G.F. Resistance of common groundsel to simazine and atrazine. Weed Science, v.18, p. 614-616, 1970. Available from: $<$ https://doi.org/10.1017/S0043174500034330>. Accessed: Jan. 02, 2020. doi:10.1017/S0043174500034330.

ROLA, J.; FRANEK, M. The inclusion of oilseed rape herbicides in agronomy systems. In: British Crop Protection Conference Weeds, Brighton, England: Bcpc Publications, 1985. p.217-222.

ROTCHES-RIBALTA, et al. Herbicide impact on the growth and reproduction of characteristic and rare arable weeds of winter cereal fields. Ecotoxicology, v.24, p.991-1003, 2015. Available from: <https://doi.org/10.1007/s10646-015-1440-x>. Accessed: Jan. 02, 2020. doi: 10.1007/s10646-015-1440-x.

SINGH, H.P., et al. Handbook of Sustainable Weed Management New York, United States: Haworth Press, 2006. Chap.2. p.19-53.

SINGH, R.P.; SRIVASTAVA, HS. Increase in glutamate synthase $(\mathrm{NADH})$ activity in maize seedlings in response to nitrate and ammonium nitrogen. Physiologia Plantarum, v.66, p.413-416, 1986. Available from: <https://doi.org/10.1111/j.1399-3054.1986. tb05944.x>. Accessed: Jan. 02, 2020. doi: 10.1111/j.13993054.1986.tb05944.x.

SINGH, S., et al. Weed management in dry seeded rice (Oryza sativa L.) cultivated in the furrow irrigated raised-bed planting system. Crop Protection, v.25, p.487-495, 2006. Available from: $<$ https://doi.org/10.1016/j.cropro.2005.08.004>. Accessed: Jan. 02, 2020. doi: 10.1016/j.cropro.2005.08.004.
SMITH, A.E. Persistence and transformation of the herbicide $\left[{ }^{14} \mathrm{C}\right]$ glufosinate-ammonium in prairie soils under laboratory conditions. Journal of Agricultural and Food Chemistry, v. 36, p.393-397, 1988. Available from: <https://doi.org/10.1021/jf00080a036>. Accessed: Jan. 02, 2020. doi:10.1021/jf00080a036.

SUKSUNGWORN, R., et al. Phytotoxic effect of Haldina cordifolia on germination, seedling growth and root cell viability of weeds and crop plants. NJAS-Wageningen Journal of Life Sciences, v.78, p.175-181,2016. Available from: <https://doi. org/10.1016/j.njas.2016.05.008>. Accessed: Jan. 02, 2020. doi:10.1016/j.njas.2016.05.008.

TANG, Z.C. Guide to Modern Plant Physiology Experiments. Beijing, China: Science Press, 1999. 156p.

TEERARAK, M., et al. Physiological and cellular mechanisms of natural herbicide resource from Aglaia odorata Lour. on bioassay plants. Acta Physiologiae Plantarum, v.34, p.1277-1285, 2012. Available from: <https://doi.org/10.1007/s11738-011-0923-5>. Accessed: Jan. 02, 2020. doi:10.1007/s11738-011-0923-5.

VÍTEK, P., et al. Detection of herbicide effects on pigment composition and PSII photochemistry in Helianthus annuus by Raman spectroscopy and chlorophyll $a$ fluorescence. Spectrochimica Acta Part A: Molecular and Biomolecular Spectroscopy, v.170, p.234-241, 2017. Available from: <https:// doi.org/10.1016/j.saa.2016.07.025>. Accessed: Jan. 02, 2020. doi: 10.1016/j.saa.2016.07.025.

WENDLER, C., et al. Effect of phosphinothricin (glufosinate) on photosynthesis and photorespiration of $\mathrm{C}_{3}$ and $\mathrm{C}_{4}$ plants. Photosynthesis Research, v.24, p.55-61, 1990. Available from: $<$ https://doi.org/10.1007/BF00032644>. Accessed: Jan. 02, 2020. doi:10.1007/BF00032644.

XIE, J., et al. The effect of glufosinate on nitrogen assimilation at the physiological, biochemical and molecular levels in Phaeodactylum tricornutum. Ecotoxicology, v.23, p.1430-1438, 2014. Available from: https://doi.org/10.1007/s10646-014-1285-8>. Accessed: Jan. 02, 2020. doi: 10.1007/s10646-014-1285-8.

$\mathrm{XU}$, J., et al. Adsorption behavior and mechanism of glufosinate onto goethite. Science of the Total Environment, v.560-561, p.123-130, 2016. Available from: $<$ https://doi.org/10.1016/j.scitotenv.2016.03.239>. Accessed: Jan. 02, 2020. doi: 10.1016/j.scitotenv.2016.03.239.

ZOU, Q. Experimental guide to plant physiology. Beijing, China: China Agriculture Press, 2000. 85p. 